Thorning, L. 1993: Preliminary aeromagnetic anomaly map (including 3 maps). In SUPRASYD 1992 field report, 6-9. Unpubl. intern. GGU rep.

Thorning, L. \& Hansen, E. 1993: Gravity measurements in South Greenland 1992 (including 9 maps). In SUPRASYD 1992 field report, 2-4. Unpubl. intern. GGU rep.

Tukiainen, T. \& Erfurt, P. in press: Application of SPOT and LANDSAT TM imageries to geological reconnaissance mapping, South Greenland. Open File Ser. Grønlands geol. Unders.
T. F. D. N., P. R. D. \& H. K. S., Geological Survey of Greenland, Copenhagen

B. C., Earth Resources Centre, University of Exeter, Exeter EX4 4QE, U.K.

R. A. F, Geological Survey of Canada, 601 Booth Street, Ottawa KIA OE8, Canada

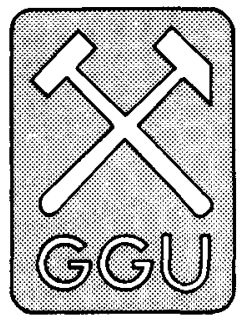

\section{Geochemical mapping and geological reconnaissance in the Nagssugtoqidian mobile belt, West Greenland}

\author{
Agnete Steenfelt, Feiko Kalsbeek \\ and Hans F. Jepsen
}

The Early Proterozoic Nagssugtoqidian mobile belt is geologically poorly known despite its location in the more populated part of West Greenland (Fig. 1). A detailed geological map (1:100 000; Olesen, 1984) is available for the western part of the Nordre Strømfjord area, but the remaining areas have only been mapped at 1:500 000 scale with geological reconnaissance along the coast and aerial photograph interpretation of inland areas (Map sheet 3: Søndre Strømfjord - Nûgssuaq; Escher, 1971).

The Nagssugtoqidian mobile belt has recently been interpreted as an area of continent-continent collision based on occurrences of Proterozoic calc-alkaline plutonic and volcanic rocks with isotope compositions reflecting a juvenile origin (Kalsbeek et al., 1987).

The re-interpretation of the Nagssugtoqidian belt from an ensialic (within-plate) feature to a suture zone between two Archaean crustal blocks changes the perception of the area's mineral potential. Existence of an early Proterozoic ocean and subduction zone would be favourable for the genesis of a number of ore deposit types, some of which might have survived later deformation and metamorphism. It is, therefore, important to look for further evidence to confirm or reject the collision model.

New geochemical data have been acquired and supplementary field observations made during GGU's reconnaissance geochemical mapping programme within the mobile belt. The programme, based on stream sediment and water sampling, covered the eastern part of the Nagssugtoqidian belt in 1990 and 1991 (Steenfelt \& Dam, 1991; Steenfelt et al., 1992), while most of the western part of the belt was sampled in 1992 (Steenfelt et al., 1993). The 1992 season also included geological field work at selected localities. In addition aeromagnetic data from parts of the mobile belt (Thorning, 1984) have recently been re-processed by $L$. Thorning to improve resolution. 
Geochemical, aeromagnetic and geological features of the eastern Nagssugtoqidian belt

Stream sediment geochemical and aeromagnetic data indicate the presence of several distinct domains, separated by fairly sharp boundaries (Fig. 2). Based on field observations, the latter have tentatively been interpreted as representing thrusts and shear zones (Steenfelt \& Dam, 1991). A clear division can also be made between the northern and the southern segments of the Nagssugtoqidian belt.

The southern region is dominated by brownish, granulite facies, hypersthene or hornblende gneiss (Fig. 3). It is characterised by high concentration levels of $\mathrm{Cr}$ and Sc, a low level of Th, and it has a strongly banded magnetic pattern reflecting the thrusted nature of the terrain (Fig. 2). The northern region is an amphibolite facies terrain mainly consisting of granitic gneisses with enclaves of garnet-bearing metasediments. This region has high Th concentrations (Fig. 2D) reflecting the presence of cross-cutting granite and pegmatite veins. Magnetic patterns are weaker and non-linear, except for the anomalies over the central part of the Arfersiorfik quartz diorite (A in Fig. 2a) and the magnetic lineament following the Nordre Strømfjord shear zone (NSSZ). In the central part of the area in Fig. 2 the Th domain overlaps the $\mathrm{Cr}-\mathrm{Sc}$ domain. The data are interpreted as reflecting an assemblage of small crustal blocks, possibly representing different crustal levels, which have been juxtaposed by shearing and thrusting such as would be expected in a continent collision environment.

\section{Rock units of the pre-collision stage}

\section{Metasediments and ultramafic rocks at the head of Arfersiorfik}

GGU's 1:500 000 map sheet 3 (Søndre Strømfjord Nûgssuaq; Escher, 1971) shows extensive occurrences of metasediments as synforms surrounded by quartz diorite near the head of Arfersiorfik fjord (Fig. 3). As major outcrops of Nagssugtoqidian (Proterozoic) metasediment are not common within the belt, it was hoped that these occurrences might provide information on early phases of development of the mobile belt.

Most of the outcrops studied (at a in Fig. 3) proved to consist of strongly deformed garnet-sillimanite paragneisses. The paragneisses host numerous large lenticular bodies of ultramafic rock, up to hundreds of metres in size. Large outcrops of amphibolite are also present. It is estimated that $c .25 \%$ of the outcrop area visited (c. $10 \mathrm{~km}^{2}$ ) consists of ultramafic bodies and $c .10 \%$ of amphibolite. Contacts between these bodies and the surrounding paragneiss are too strongly sheared to permit an interpretation of their original mutual relationships. Much of the surrounding quartzo-feldspathic orthogneiss is very homogeneous. A correlation with the Arfersiorfik quartz diorite, as suggested on the published map, would seem likely, although the rock is much more felsic than the quartz diorites north-east of the head of Arfersiorfik.

The paragneisses form an east-plunging synform within the surrounding orthogneisses. It is believed that this synform is a late structure because the paragneisses have a strong foliation, and it is this foliation that is folded by the main synform. The contact between the paragneisses and the surrounding orthogneisses is too strongly sheared to yield evidence of the original relationship between the two rocks.

There are few streams in the area near locality a (Fig. 3 ). The closest two stream sediment samples have been collected to the west of the outcropping ultramafic rocks, and they did not have the chemical signatures of ultramafic rocks. By contrast, a strong multi-element anomaly with high $\mathrm{Mg}, \mathrm{Ti}, \mathrm{Cr}, \mathrm{Co}, \mathrm{Ni}, \mathrm{Cu}, \mathrm{Zn}, \mathrm{As}, \mathrm{Sb}$ and $U$ was detected in 1991 at locality b (Fig. 3) on the northern side of the Nordre Strømfjord shear zone (Steenfelt et al., 1992). When inspected in the field in 1992 it was shown to reflect a large ultramafic body (source of $\mathrm{Mg}, \mathrm{Ti}, \mathrm{Cr}, \mathrm{Co}$ and $\mathrm{Ni}$ ) in contact with rusty biotite schist (source of $\mathrm{Cu}, \mathrm{Zn}$, As and $\mathrm{Sb}$ ) and crosscut by conspicuous pegmatite veins (source of $U$ ). On the 1:500 000 geological map this ultramafic rock is erroneously shown as marble.

\section{Sarfartuup Nunaa, south-east of Søndre Strømfjord}

An outcrop at Sarfartuup Nunaa several $\mathrm{km}^{2}$ in area and dominated by greenschists and amphibolites ( $\mathrm{S}$ in Fig. 1) has been interpreted as a klippe of Nagssugtoqidian supracrustal rocks by Diggens \& Talbot (1974) and Talbot (1979). Talbot (1979) recognised a sequence of at least nine thrust sheets piled up on top of each other, several of the sheets containing basement gneisses with an unconformable cover of sediments and basic volcanic rocks. During our visit in 1992 it was not possible to confirm this interpretation.

The Sarfartuup Nunaa outcrops lie on a plateau at $c$. $1200 \mathrm{~m}$ altitude, and although most rocks are probably more or less in place, much of the outcrop is frost shattered, and detailed observations are therefore commonly impossible. All proposed thrust contacts shown on Talbot's (1979) map are covered by debris and impossible to verify. Convincing evidence of an unconformable relationship between orthogneisses and meta- 

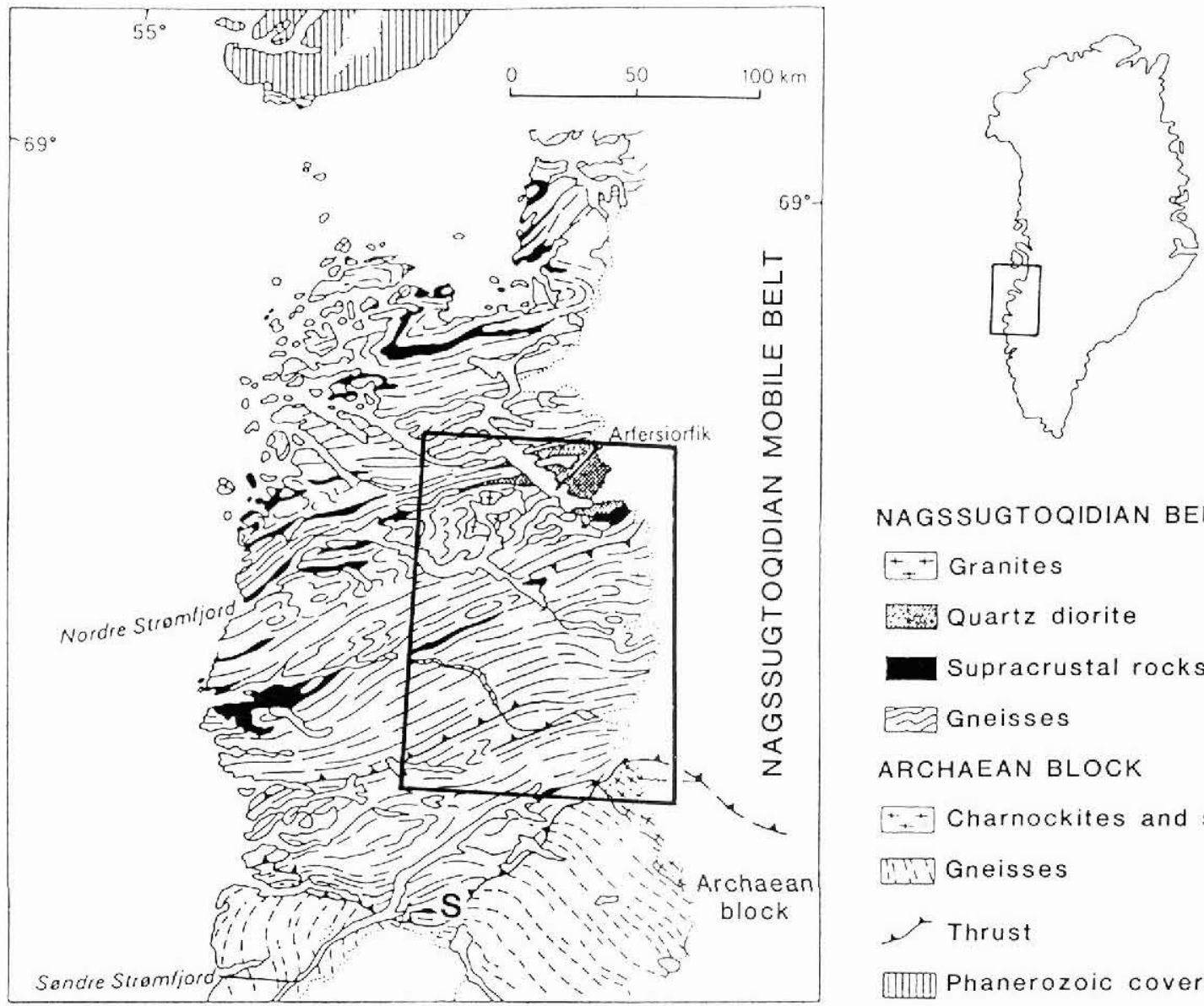

NAGSSUGTOQIDIAN BELT

$\because$ Granites

Wuartz diorite

Supracrustal rocks

Gneisses

ARCHAEAN BLOCK

$\because$ Charnockites and syenites

III Gneisses

Thrust

(11III) Phanerozoic cover

Fig. 1. Location of the Nagssugtoqidian mobile belt in West Greenland. The frame shows the area of Fig. 2. S indicates the locality Sarfartuup Nunaa which is discussed in the text.

sediments or mafic volcanic rocks was not found. Loose blocks of leucocratic fine-grained gneiss occur at localities mapped by Talbot (1979) as metasediments, but the origin of these rocks is not clear. Greenschists and amphibolitic rocks do locally show structures which may be interpreted as poorly preserved pillows, but also here there was no evidence of an unconformable relationship with the gneisses.

The Sarfartuup Nunaa area lies within a major shear zone, and most of the rocks are very strongly deformed. The surrounding gneisses contain numerous dykes of the Kangâmiut dyke swarm. Similar basic intrusive rocks on Sarfartuup Nunaa were interpreted by Talbot (1979) as late metabasic intrusions emplaced into the Nagssugtogidian supracrustal pile before southward tectonic transport of the whole mass into its present position. However, we favour the interpretation that parts of the greenschist-amphibolite sequence are of $\mathrm{Ar}$ chaean age and comparable with Archaean amphibolites elsewhere, and that others are strongly deformed intrusive bodies belonging to the Kangâmiut swarm. Indeed, some of these bodies are massive in their centres, but transformed into greenschist along their margins.

\section{Rock units and structures of the collision stage}

\section{Granitic rocks in the eastern part of Nordre} Strømfjord

In the eastern part of Nordre Strømfjord the 1:500 000 geological map shows large outcrops of granitoid rocks. Some of these ( $\mathrm{g} 1$ and $\mathrm{g} 2$ in Fig. 3 ) are of trondhjemitic affinity; they have low levels of gamma radiation as measured with a scintillometer (Steenfelt \& Dam, 1991) and are grey to white in colour. Others ( $g 3$ and g4) are pink potassium-rich granites with higher gamma-radiation. The latter have been interpreted as syn-collision granites by Kalsbeek et al. (1987). Large outcrops of granite have also been found to be present 
in areas indicated as gneiss on the 1:500 000 published map.

The granite outcrop at $\mathrm{g} 4$ was studied in some detail. It is surrounded by metasediments (quartzite, marble and paragneiss), and is full of rafts and inclusions of gneiss and amphibolite, commonly well preserved but sometimes half-digested. Only parts of the outcrop, rarely larger than tens of metres in extent, consist of homogeneous granite.

The metasediments that overlie the granite at $\mathrm{g} 4$ are well preserved. To the north-east the contact is sharp and concordant on outcrop scale. A few metres thick quartzite layer, in direct contact with the granite, is overlain by several tens of metres of marble, and this is in turn overlain by semipelitic paragneisses. The contact is reminiscent of the basal unconformities seen elsewhere in West Greenland where Proterozoic sediments overlie Archaean basement (e.g. Henderson \& Pulvertaft, 1987). However, on a larger scale the granite is discordant with respect to the metasediments; to the south the granite is in direct contact with pelitic metasediments. The granite cannot, therefore, represent Archaean basement rocks, but it may have been emplaced along the contact between Archaean basement gneisses and the Proterozoic sedimentary cover.

\section{Structures in the eastern part of the area between Søndre and Nordre Strømfjord}

The intense deformation affecting the area between Søndre Strømfjord and Nordre Strømfjord can be ascribed to the collision phase of the Proterozoic orogeny. In the southern part of the investigated region ENEWSW structural trends are very pronounced, and there are several steep, subparallel zones of intense shearing. The most pronounced have been traced as topographical lineaments on aerial photographs (lines 1 to 3 in Fig. 3) and they coincide with magnetic linear trends in the strongly banded pattern on the aeromagnetic map (Fig. 2a). Line 1 runs through amphibolite facies gneisses with Kangâmiut dykes and coincides with a very distinct boundary between highly magnetised rocks north of the line and less magnetised rocks south of it. Line 3 coincides largely with the thrust indicated on GGU's 1:500 000 map as following the southern boundary of the hypersthene gneiss terrain. Towards the west the three major and some intermediate minor lineaments appear to merge into the Ikertôq shear belt (Grocott, 1979; Korstgård, 1979). Within the belt these authors recognised pre-Kangâmiut dyke transcurrent shearing overprinted by post-dyke ductile thrusting in the northern part. In the area north of Kangerlussuaq (formerly Søndre Strømfjord) Airport, Kangâmiut dykes are affected by displacements along lineaments 2 and 3 whereas the relationship of line 1 with the dykes has not been verified.

Between line 4 and an observed brittle fault (5 in Fig. 3) light brown gneiss is overridden by sheared grey biotite gneiss containing disseminated sulphides and graphite. The sheared gneiss is very gently inclined $\left(10^{\circ}\right.$ to $20^{\circ} \mathrm{N}$ ) and line 4 is believed to represent a flat-lying thrust.

North of line 6 in Fig. 3 the regional strain weakens and the terrain is characterised by open folds in the grey gneiss with extensive enclaves of supracrustal rocks. Line 6 was mapped as a thrust with northward displacement on the 1:500 000 geological map. The thrust has not been studied on the ground, but appears important as it coincides with a magnetic lineament (Fig. 2a) and in its easternmost part with a geochemical boundary seen as a sharp change in background level for Sc (Fig. 2c), as well as for Ba and Ca (Steenfelt \& Dam, 1991).

\section{Indications of mineralisation}

Observations of zones of rusty weathering were made routinely in connection with the geochemical sampling and plotted on aerial photographs. Rust colouring is widespread and is typically associated with supracrustal rocks in shear and thrust zones, particularly in the Nordre Strømfjord shear zone. Ground inspection showed that the hosts of the rust zones are commonly mica schist or gneiss, and occasionally amphibolite. Non-weathered sulphide minerals are rarely seen but graphite is common to abundant.

The geochemical data show that enrichment in $\mathrm{Cu}$, $\mathrm{Zn}$ and As has occurred in the shear zones and also that the concentration of fluoride is higher in the water of streams draining such zones. The observations indicate that the zones have been subjected to hydrothermal water flow, and mineralisation may have taken place where conditions were favourable (Steenfelt et al., 1992). The distribution of $\mathrm{Au}, \mathrm{As}$ and $\mathrm{Sb}$ anomalies indicates possible gold mineralisation in supracrustal

Fig. 2. Aeromagnetic map (a) and the distribution of chromium (Cr), scandium ( $\mathrm{Sc}$ ) and thorium (Th) concentrations in stream sediments in the eastern part of the Nagssugtoqidian mobile belt. The shaded relief map (illuminated from the north) of the total magnetic field is based on reprocessing of measurements from 3000 feet altitude and $1.5 \mathrm{~km}$ line spacing (Thorning, 1984). The map emphasises the linear trends but does not show the levels of magnetisation. The element distribution maps are based on instrumental neutron activation analysis of the $<0.1 \mathrm{~mm}$ fraction of stream sediment. 


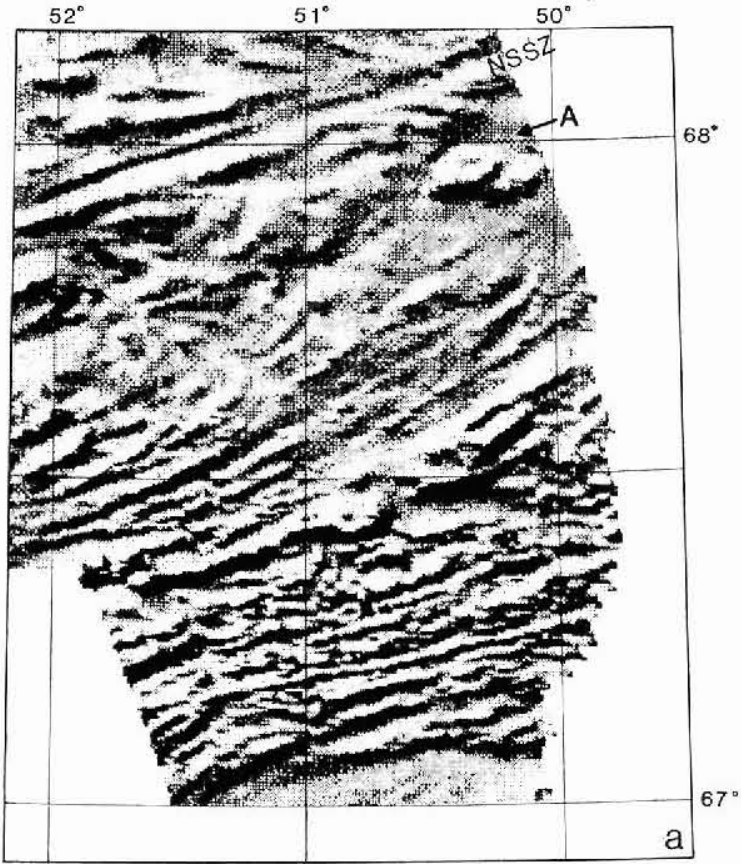

$50 \mathrm{~km}$

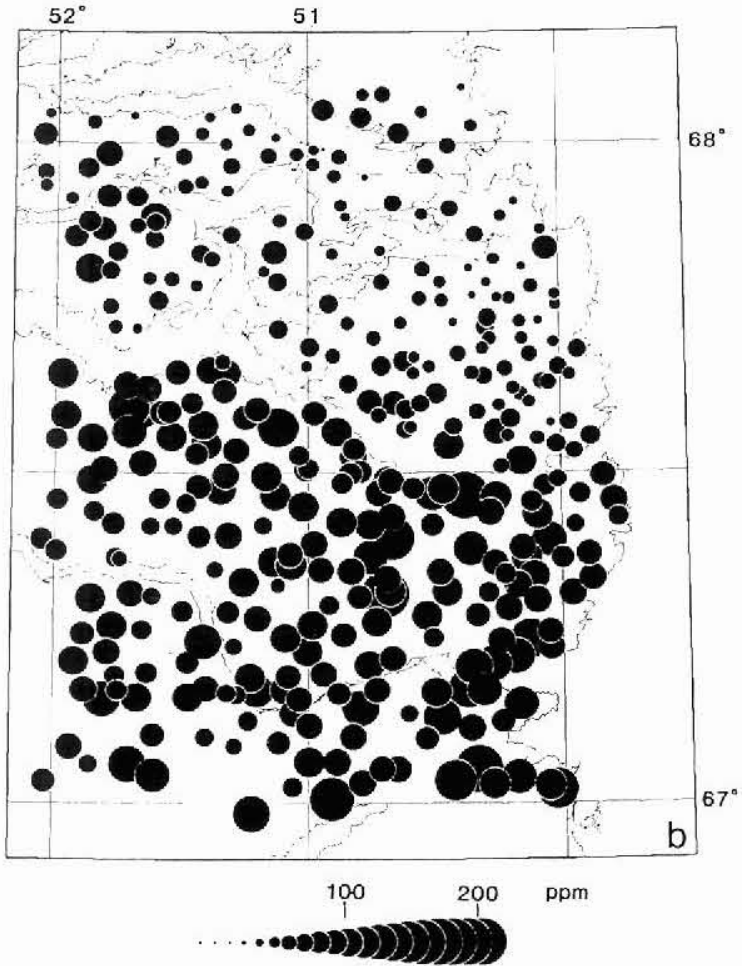

$\mathrm{Cr}$ in stream sediment

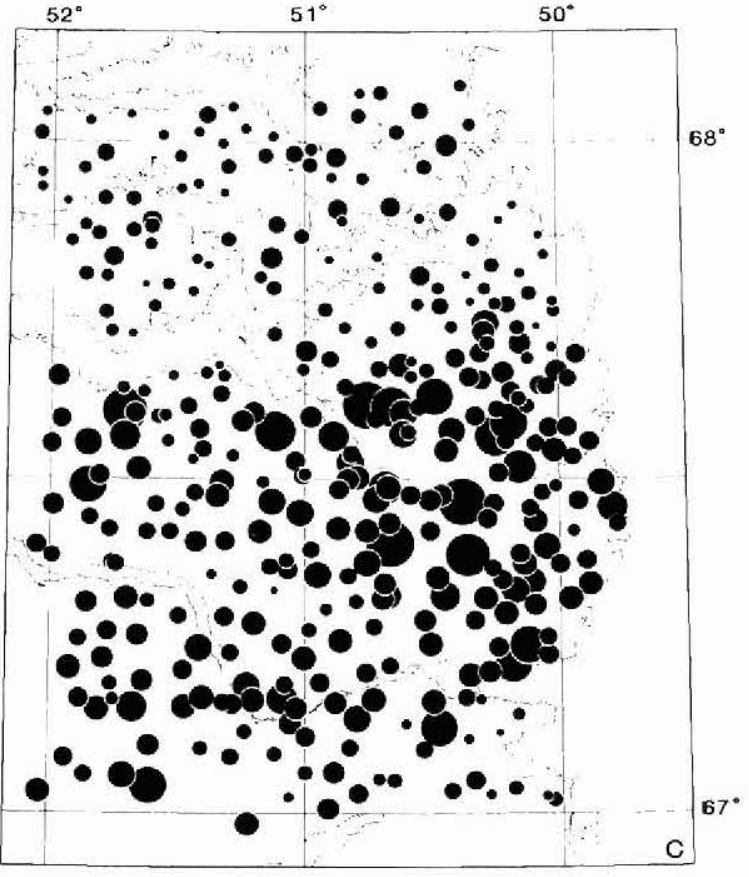

${ }_{10}^{10}$

Sc in stream sediment

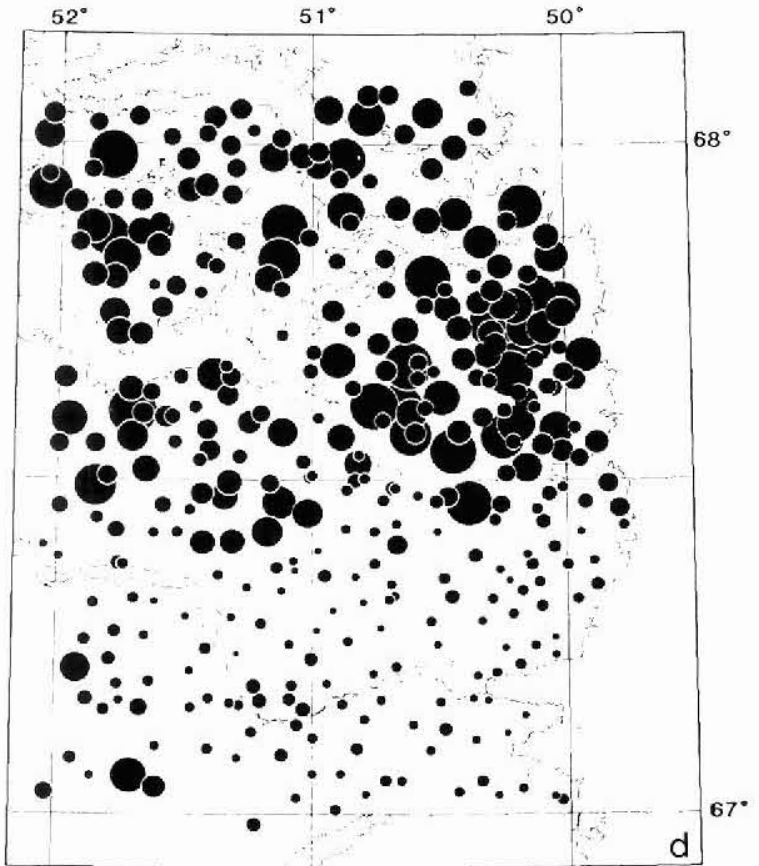

$\cdots$

Th in stream sediment 


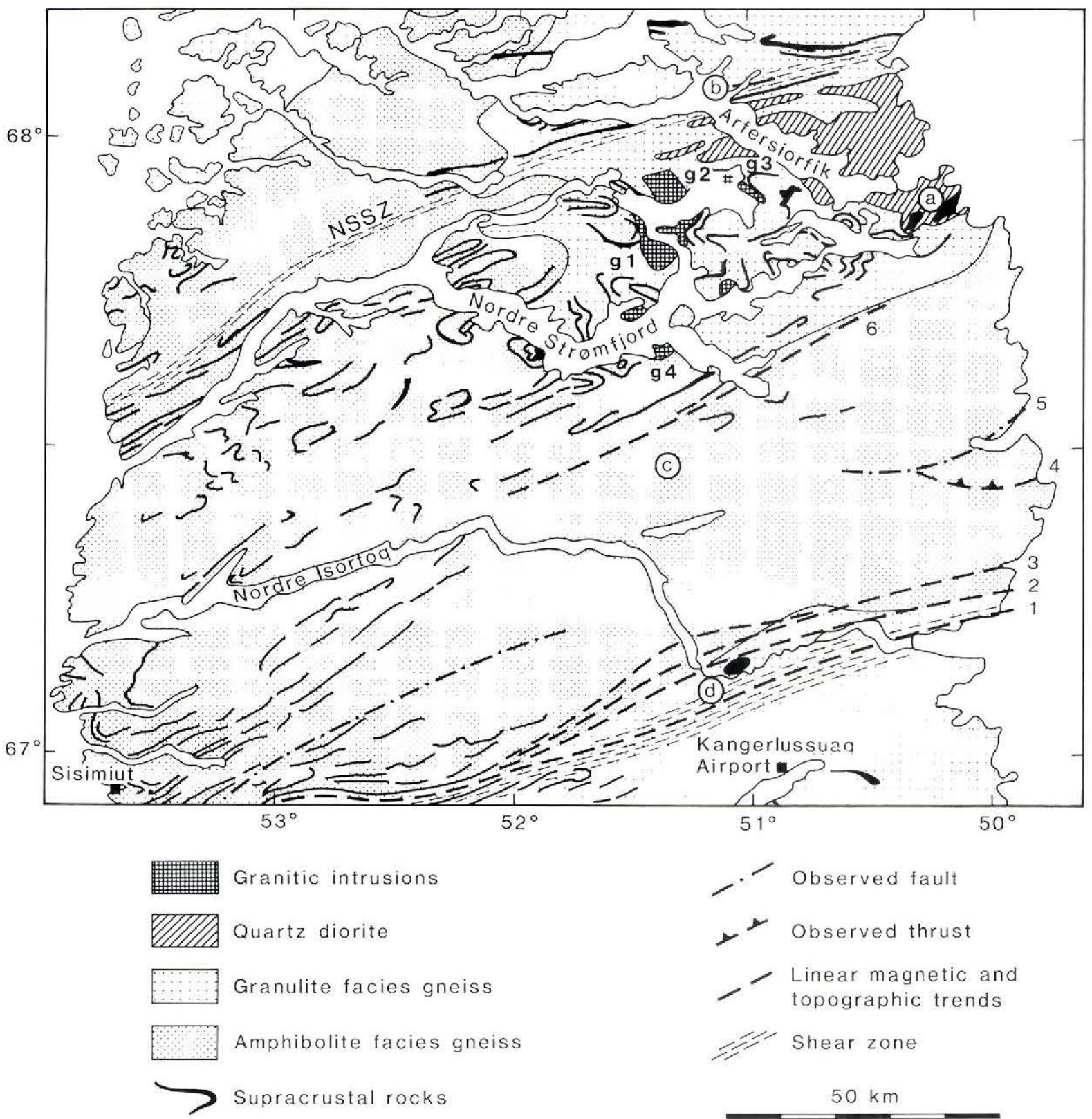

Fig. 3. Simplified geology of the Nagssugtoqidian mobile belt after Escher (1971) with major lineaments ( 1 to 6 ) and localities (a to g) mentioned in the text.

sequences in the northern part of the Nagssugtoqidian belt (Steenfelt. 1992).

Evidence for hydrothermal alteration was also found at localities $\mathrm{c}$ and $\mathrm{d}$ in Fig. 3. At locality $\mathrm{c}$ the orthogneisses weather yellow in a $c .1 .5 \mathrm{~km}$ wide ENE trending zone. On the 1:500 000 geological map this zone is erroneously shown as metasediments. At locality d a 1-2 $\mathrm{m}$ wide yellowish rusty alteration zone runs discordantly through a large body of garnet rich meta- gabbro. Compared to the host rock the alteration zone is enriched in $\mathrm{Zn}(640 \mathrm{ppm}) . \mathrm{K}\left(5.25 \% \mathrm{~K}_{2} \mathrm{O}\right)$ and $\mathrm{Rb}$ (166 ppm).

\section{Conclusions}

The 1992 sampling has completed the geochemical low-density coverage of the Nagssugtoqidian mobile belt, and the analytical data contribute to an overview 
of the mineralisation potential as well as providing a basis for recognition of crustal domains involved in the Nagssugtoqidian mobile belt.

Geological reconnaissance has shown that the southern part of GGU's 1:500 000 map sheet 3 (Søndre Strømfjord - Nûgssuaq; Escher, 1971) is unreliable in important respects. This is mainly due to lack of sufficient ground control in large parts of the area prior to map compilation. Further study of the Nagssugtoqidian belt is thus justified. Although strongly deformed and metamorphosed, the metasediments east of Arfersiorfik may provide possibilities for a study of the earliest stages of evolution of the Nagssugtoqidian mobile belt. It is still an open question whether these outcrops represent early Proterozoic sediments, whether the ultramafic bodies are obducted parts of early Proterozoic ocean floor and whether the early stages of plate convergence were associated by formation of ore bodies. The rocks at Sarfartuup Nunaa, where it was hoped to gain an insight into early Nagssugtoqidian sedimentation and volcanism, do not appear to be suitable for this kind of study.

Acknowledgements. The Mineral Resources Administration for Greenland contributed financially to the geochemical mapping programmes in 1991 and 1992. Leif Thorning kindly gave permission to present the aeromagnetic map in Fig. 2.

\section{References}

Diggens, J. \& Talbot, C. 1974: Nagssugtoqidian supracrustal metavolcanic rocks of Sarfartûp nunâ, Søndre Strømfjord, central West Greenland. Rapp. Grønlands geol. Unders. 65, 37-39.

Escher, A. 1971: Geological map of Greenland. 1:500 000 sheet 3, Søndre Strømfjord - Nûgssuaq. Copenhagen: Grønlands Geologiske Undersøgelse.

Grocott, J. 1979: Controls of metamorphic grade in shear belts. Rapp. Grønlands geol. Unders. 89, 47-62.

Henderson, G. \& Pulvertaft, T. C. R. 1987: Lithostratigraphy and structure of a Lower Proterozoic dome and nappe complex. Descriptive text to $1: 100,000$ sheets Mârmorilik 71 V.2 Syd, Nûgâtsiaq 71 V.2 Nord and Pangnertôq 72 V.2 Syd, 72 pp. Copenhagen: Grønlands Geologiske Undersøgelse.

Kalsbeek, F., Pidgeon, R. T. \& Taylor, P. N. 1987: Nagssugtoqidian mobile belt of West Greenland: a cryptic $1850 \mathrm{Ma}$ suture between two Archaean continents - chemical and isotopic evidence. Earth Planet. Sci. Lett. 85, 365-385.

Korstgård, J. A. 1979: Metamorphism of the Kangâmiut dykes and the metamorphic and structural evolution of the southern Nagssugtoqidian boundary in the Itivdleq-Ikertôq region, West Greenland. Rapp. Grønlands geol. Unders. 89, 63-75.

Olesen, N. Ø. 1984: Geologisk kort over Grønland 1:100 000, Agto 67 V.1 Nord. Copenhagen: Grønlands Geologiske Undersøgelse.

Steenfelt, A. 1992: Gold, arsenic and antimony in stream sediment related to supracrustal units between Arfersiorfik and Qarajaq Isfjord $\left(68^{\circ} \mathrm{N}\right.$ to $\left.70^{\circ} 30^{\prime} \mathrm{N}\right)$, West Greenland. Open File Ser. Grønlands geol. Unders. 92/4, 11 pp.

Steenfelt, A. \& Dam, E. 1991: Reconnaissance geochemical exploration of map sheet $67 \mathrm{~V} .2\left(67^{\circ}\right.$ to $68^{\circ} \mathrm{N}, 49^{\circ} 30^{\prime}$ to $52^{\circ} \mathrm{W}$ ), West Greenland. Open File Ser. Grønlands geol. Unders. 91/8, 13 pp.

Steenfelt, A., Dam, E. \& Nielsen, J. P. 1992: Reconnaissance geochemical exploration of map sheet $68 \mathrm{~V} .2\left(67^{\circ} 55^{\prime}\right.$ to $68^{\circ} 45^{\prime} \mathrm{N}, 50^{\circ} 15^{\prime}$ to $52^{\circ} 45^{\prime} \mathrm{W}$ ), West Greenland. Open File Ser. Grønlands geol. Unders. 92/7, $20 \mathrm{pp}$.

Steenfelt, A., Dam, E. \& Nielsen, J. P. 1993: Reconnaissance geochemical mapping of map sheets $67 \mathrm{~V} .1$ and $68 \mathrm{~V} .1\left(66^{\circ}\right.$ to $68^{\circ} \mathrm{N}, 51^{\circ} 40^{\prime}$ to $\left.54^{\circ} \mathrm{W}\right)$, West Greenland. Open File Ser. Grønlands geol. Unders. 93/1, $20 \mathrm{pp}$.

Talbot, C. J. 1979: A klippe of Nagssugtoqidian supracrustal rocks at Sarfartûp nunâ, central West Greenland. Rapp. Grønlands geol. Unders. 89, 23-42.

Thorning, L. 1984: Aeromagnetic maps of parts of southern and central West Greenland: acquisition, compilation and general analysis of data. Rapp. Grønlands geol. Unders. 122, $36 \mathrm{pp}$.

A. S., F. K. \& H. F. J., Geological Survey of Greenland, Copenhagen. 